and more particularly the mental equipment of the trout, its senses and their modes of action. This is done in the light of comparative psychology to a considerable extent, but also in the light of a great deal of actual observation by the author and other experienced anglers.

Certain writers tend to endow the trout with almost superhuman attributes, an attitude explained thus: "The rest of the truth is that be we never so skilful, boast we half a century of experience, we can catch trout but little more easily -if at all-than when we were striplings. There must be something in it-quite obviously trout are extremely cunning fish." A quotation from such a eulogy serves as an excellent Aunt Sally to be knocked down by the author with consider- able gusto. What are the parts played by instinct and intelligence in this cunning ? Can the fish profit by experience? Why do they rise? To what extent are they capable of distinguishing flies or other bait? Why are there often two types of trout in the same water? These and other problems that have been pondered by fishermen since first a fly was cast or a minnow spun, are treated in an engaging manner which never becomes tedious or didactic, although the opinions put forward are well documented by footnotes. The pure dry-fly man comes in for some delightful gibes, but they are always kindly and never sneering. It is just the book for the fisherman to take with him on his trip, for he will find in it much food for thought and new side-lights on old problems.

\title{
Review of Biochemistry
}

Handbuch der Biochemie des Menschen und der Tiere

Herausgegeben von Prof. Dr. Carl Oppenheimer. Zweite Auflage. Ergänzungswerk, Band 3. Pp. xxiv + 1162. (Jena: Gustav Fischer, 1936.) 84 gold marks.

IN previous reviews of this Brobdingnagian offspring (see NATURE, 133, $595 ; 1934$; and 135, $287 ; 1935)$ we have already commented on its dimensions and the deducible dimensions of its parent. In this third volume of the "Ergänzungswerk" to the second edition of the "Handbuch" we have 1,136 pages of text and 25 pages of index, giving a total almost identical with that of the first volume ; this was, however, published in two half-volumes of about 600 pages each, and there is no clue to the reason for the production of this monster between a single pair of covers.

This third volume is supplementary to vols. 7-9 (Parts 8-10) of the main volume. It covers metabolism under special conditions, including the processes of birds, cold-blooded animals, and invertebrates; metabolism under physiological conditions, including growth, pregnancy, heavy labour, hunger and under-nutrition, variations of climate, and radiation; metabolism under the influence of secretions and of endocrine disturbances; metabolism under various pathological conditions, including fevers, nervous disturbances and deficiency diseases; and the metabolism of the female generative system. These various sections constitute the supplementary material to Part 8 of the main volume.

The supplementary material to Part 9 is concerned chiefly with the metabolism of particular organs and tissues, including tumour tissue, and with the metabolism of the various essential food constituents, water, minerals, carbohydrates, proteins, creatine and creatinine, nucleides, fats and lipoids. Part 10 is supplemented by a survey of all those subjects that are comprised under the general phrase "Regulation of Function"-including both non-specific (for example, nervous) and specific regulation, as by vitamins and hormones. The section here on the biochemistry of the sexual hormones is, incidentally, described in a note as itself supplementing Dr. Butenandt's contribution to the first supplementary volume, published in 1933 - a clear demonstration of the exceptionally rapid progress now being made in the field. Separate sections in the supplement to Part 10 are devoted to the physiology of the various endocrine organs. Finally, there is a useful addendum on the sterols, bile acids, and inositol.

As in the previous supplementary volumes, the names of many of the contributors are biochemical household words. Avon, Krüger, Lehmann, Pincussen, Felix, Fürth, Grafe are among the professorial contributors, supported by a number of Privat-Dozenten to a total of some twenty. This volume completes the task of supplementing the "Handbuch's" second edition. It maintains the authoritative character of the other two volumes and constitutes with them a quite indispensable whole.

Words almost fail one at the scope and completeness of the "Handbuch" and the supplementary volumes. If a reviewer may be permitted to repeat himself, it can once more be stated that "these volumes are of the kind that fill the user with awe-inspired gratitude and the reviewer with awe-inspired terror". $\quad$ A. L. BACHARACH. 